\title{
Structuring sustainability science
}

\author{
Anne Jerneck $\cdot$ Lennart Olsson $\cdot$ Barry Ness $\cdot$ Stefan Anderberg $\cdot$ \\ Matthias Baier - Eric Clark - Thomas Hickler • Alf Hornborg • \\ Annica Kronsell · Eva Lövbrand · Johannes Persson
}

Received: 1 March 2010/ Accepted: 2 August 2010/Published online: 24 August 2010

(C) Integrated Research System for Sustainability Science, United Nations University, and Springer 2010

\begin{abstract}
It is urgent in science and society to address climate change and other sustainability challenges such as biodiversity loss, deforestation, depletion of marine fish stocks, global ill-health, land degradation, land use change and water scarcity. Sustainability science (SS) is an attempt to bridge the natural and social sciences for seeking creative solutions to these complex challenges. In this article, we propose a research agenda that advances the
\end{abstract}

Edited by Fukuya lino, United Nations Industrial Development Organization (UNIDO), Austria.

A. Jerneck $\cdot$ L. Olsson $(\bowtie) \cdot$ B. Ness $\cdot$ S. Anderberg Lund University Centre for Sustainability Studies (LUCSUS), Box 170, 22100 Lund, Sweden

e-mail: Lennart.Olsson@lucsus.lu.se

\section{Baier}

Division of Sociology of Law, Lund University, Lund, Sweden

E. Clark

Department of Human Geography, Lund University, Lund, Sweden

T. Hickler

Biodiversity and Climate Research Centre (BiK-F),

Frankfurt am Main, Germany

A. Hornborg

Division of Human Ecology, Lund University, Lund, Sweden

A. Kronsell

Department of Political Science, Lund University, Lund, Sweden

E. Lövbrand

Centre for Climate Science and Policy Research,

Linköping University, Linköping, Sweden

J. Persson

Department of Philosophy, Lund University, Lund, Sweden methodological and theoretical understanding of what SS can be, how it can be pursued and what it can contribute. The key focus is on knowledge structuring. For that purpose, we designed a generic research platform organised as a three-dimensional matrix comprising three components: core themes (scientific understanding, sustainability goals, sustainability pathways); cross-cutting critical and problem-solving approaches; and any combination of the sustainability challenges above. As an example, we insert four sustainability challenges into the matrix (biodiversity loss, climate change, land use changes, water scarcity). Based on the matrix with the four challenges, we discuss three issues for advancing theory and methodology in SS: how new synergies across natural and social sciences can be created; how integrated theories for understanding and responding to complex sustainability issues can be developed; and how theories and concepts in economics, gender studies, geography, political science and sociology can be applied in SS. The generic research platform serves to structure and create new knowledge in SS and is a tool for exploring any set of sustainability challenges. The combined critical and problem-solving approach is essential.

Keywords Climate change - Critical research . Problem-solving research - Sustainability challenges . Sustainability pathways $\cdot$ Transdisciplinarity

\section{The problem and the vision}

Strong messages about the state of the planet are expressed by large scientific communities: the Millennium Ecosystem Assessment (Reid et al. 2005), the Stern Review (Stern 2006), the Fourth Assessment Report by IPCC 2007a), the fourth Global Environmental Outlook (UNEP 2007) and 
the Human Development Reports (UNDP 2007, 2009). Moreover, the World Bank joins this chorus with a dire outlook on global food security and climate change impacts (World Bank 2007, 2009). In synthesis, anthropogenic influences on global life support systems have reached a magnitude unprecedented in human history, levels that now jeopardise the well-being of humanity. This demands action in many domains of science and society. To that end, this article suggests how research can be organised, structured and conducted in pursuit of sustainability.

Despite profound changes in nature ${ }^{1}$ and society, the disciplinary organisation of scientific knowledge production largely remains unchanged (Nature 2007). At the same time, it is recognised that we should address sustainability in interdisciplinary rather than disciplinary ways. If the academic divide between the natural and social sciences hampers the ability to study, cope with and raise awareness on challenges like climate change, then it is promising to see that systematic sustainability research is eventually making strong imprints in academia in terms of increased collaboration in research and education across disciplines and faculties (Deutsch 2007; Biermann et al. 2009; FerrerBalas et al. 2010). The emerging field of sustainability science is a major attempt to bridge the divides and fill the many knowledge gaps as invitingly described in this inspirational quote:

It is not yet an autonomous field or discipline, but rather a vibrant arena that is bringing together scholarship and practice, global and local perspectives from north and south, and disciplines across the natural and social sciences, engineering, and medicine. Its scope of core questions, criteria for quality control, and membership are consequently in substantial flux, and may be expected to remain so for some time. Something different is surely "in the air"-something that is intellectually exciting, practically compelling, and might as well be called "sustainability science". (Clark and Dickson 2003)

Sustainability science was consolidated as an international science policy project in the preparations for the World Summit on Sustainable Development in Johannesburg in 2002. The concept articulates a new vision of harnessing science for a transition towards sustainability and is, thus, an attempt to strengthen the dialogue between science and society (Clark and Dickson 2003; Weaver and Jansen 2004; Jäger 2009a, b). Although heterogeneous in scope and practice, the emerging research field mainly

\footnotetext{
${ }^{1}$ Over the last 50 years, the species extinction rate is over 1,000 times higher than the background rate (Chivian and Bernstein 2008). The rate of global temperature increase is unprecedented for at least 10,000 years (IPCC 2007a).
}

draws upon scholarly attempts that rethink interactions across domains and scales, primarily those between: nature and society (Schellnhuber 1999; Hornborg and Crumley 2006); science and democracy (Irwin 1995; Kleinman 2001; Leach et al. 2007); the global and the local (Jasanoff and Martello 2004); as well as the past, the present and possible futures (Rotmans et al. 2001). By redefining the functions, mandate and scope of scientific inquiry, sustainability science seeks to be responsive to the needs of and values in society while preserving the life-support systems of planet Earth (Kates et al. 2001; Bäckstrand 2003). This requires new integrated approaches.

There is a strong natural science consensus on many of the fundamentals of the new sustainability challenges. This is a reflection of how the natural sciences operate under paradigms that strive for scientific objectivity, reduced uncertainty and scientific agreement as epitomised by the bottom line consensus in climate change ${ }^{2}$ (Oreskes 2004). However, social scientists may misinterpret the 'uncertainty' in natural science debates as an indicator of scientific disagreement. In that respect, it can be argued that the social sciences lack a profound understanding of natural science research. On the other hand, advocates of sustainability science who are firmly grounded in the natural sciences and syntheses thereof may be less theoretically and methodologically versed in matters of justice, politics, power and critical research that is grounded in the social sciences. The aim in sustainability science of fostering a coherent interdisciplinary system of research planning and practice has given less room for research rooted in the social sciences and humanities that calls the basic assumptions of modern society into question. It can, therefore, be argued that global sustainability challenges cannot be understood or solved solely in the natural, medical or engineering sciences; equal efforts must be devoted to examining the challenges from other ontologies and epistemologies.

In this article, and unlike most emerging initiatives in the field, we suggest an approach that tangibly incorporates social science dimensions into sustainability science research. We proceed from Robert Cox's (1981) conceptual distinction between problem-solving and critical research and aim at finding new ways of integrating knowledge across the natural and social divides, as well as between critical and problem-solving research. The knowledge integration will be accomplished by developing a generic research platform with flexible methods that can be used for studying any combination of major

\footnotetext{
2 The bottom line consensus has three components: (1) the planet is warming, (2) this is primarily caused by increasing concentrations of greenhouse gases (GHGs) in the atmosphere and (3) these GHGs are primarily of anthropogenic origin owing to the combustion of fossil fuels and land use change.
} 
sustainability challenges, such as: climate change; biodiversity loss; depletion of marine fish stocks; land degradation; land use changes; water scarcity; and global illhealth owing to neglected tropical diseases and the major epidemics of malaria, tuberculosis and HIV/AIDS (Hotez et al. 2007). Throughout the article, we discuss themes, frames and concepts that can help to structure sustainability science. To exemplify specifically how research can be organised using the approach, a brief example from the Lund University Centre of Excellence for Integration of Social and Natural Dimensions of Sustainability (LUCID) is provided in "A LUCID example".

\section{Old social problems and new sustainability challenges}

There is ample social research on structural transformation, institutional shifts and systemic transition. Economists, geographers, historians and sociologists have depicted, documented and discussed how societies struggle over centuries to overcome long-standing social problems like hunger, disease, poverty and violation of human rights. Narratives on social change and the persistence of old problems are, thus, abundant.

Recently, science has identified new or escalating geo-bio-physical phenomena and processes with deep social impacts; these include biodiversity loss, land use change, water scarcity and climate change. There is a fundamental difference in the dynamics between old social problems and such new sustainability challenges. Extant problems like hunger, disease and poverty have been experienced and dealt with in isolation by people as well as collectively by society over millennia. Sustainability challenges, on the other hand, have more recently been identified by the natural sciences and communicated to society as imminent or future problems that society as a collective is just starting to understand and grapple with.

The new challenges also have important implications for the old problems. Linkages between them come into play when, for example, new challenges threaten to undermine future provisions of ecosystem services, which may, in turn, exacerbate and/or extend the old problems of poverty and unequal distribution (UNEP 2007). The recent focus on sustainability challenges, however, highlights the many threats to existing insecure livelihoods. It also fuels the attention and debate on social and environmental justice, thereby strengthening the notion that poverty, global inequality and adaptation to climate change impacts must be addressed simultaneously (Gupta et al. 2010). A schematic illustration of old (extant) social problems versus new urgent (imminent/future) sustainability challenges is presented in Fig. 1.

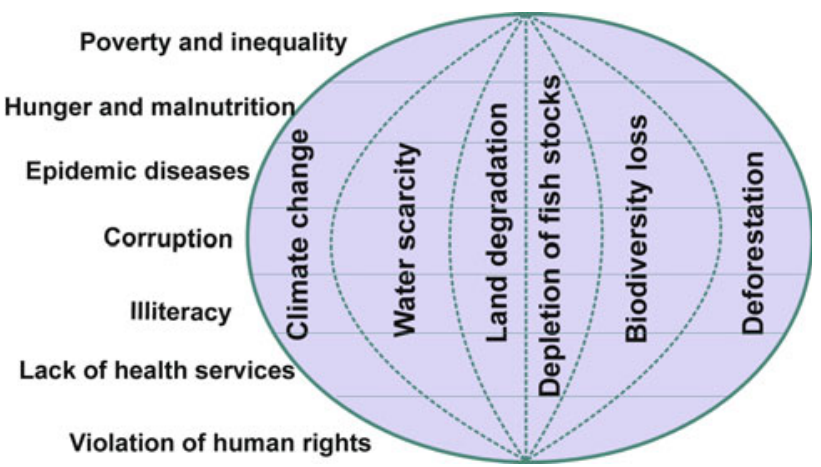

Fig. 1 Examples of 'old' social problems and 'new' sustainability challenges (in the globe)

Human effects on the planet have escalated to a point that we may reasonably speak of the Anthropocene, i.e. a geological epoch when humans dominate the shaping and reshaping of the planet (Crutzen 2002). In the Anthropocene, key environmental parameters have moved well beyond the range of natural variability experienced over the last million years to enter a non-analogue state (Crutzen and Steffen 2003), where several thresholds (HainesYoung et al. 2006) or 'planetary boundaries' (Rockström et al. 2009) are overstepped. A rising number of challenges, such as climate change, have advanced to levels where human welfare is directly and immediately threatened, while others, like biodiversity loss, pose more of potential future threats to humanity. These challenges are pervasive and may be referred to as wicked problems (Rittel and Webber 1972). Wicked problems are persistent because solutions are difficult to identify owing to complex interdependencies. And once solutions are identified, they may have incomplete, contradictory and changing requirements. While attempting to solve a wicked problem, the solution may reveal or create another even more complex problem. As an example, climate change policies that promote biofuel production may drive land use changes to an extent where biodiversity, food security and local livelihoods are put at risk, hence, an attempted solution that causes new difficult problems and conflicting concerns.

Furthermore, sustainability challenges may span several generations, and are characterised by lags and inertia, masking important causes and effects. As a consequence, many current social and political institutions are less suited to tackling the new sustainability challenges (UNEP 2007; Walker et al. 2009). Research based on the matrix in Fig. 2 may lead to insights on how to better design institutions for dealing with interconnected problem syndromes as discussed in the debate on 'Governing Sustainability' (Adger and Jordan 2009) and in the Earth System Governance Project for international collaborative research on sustainability challenges (Biermann et al. 2009). 


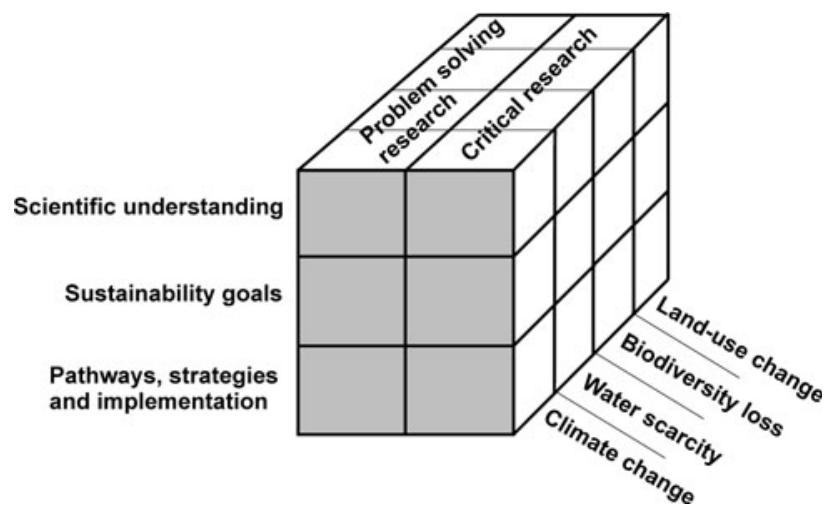

Fig. 2 The three-dimensional matrix describing how research is structured in LUCID

In sum, the present scientific understanding signals that sustainability challenges are multi-scalar, multi-faceted and strongly interrelated in complex ways that require integrated solutions across scales and domains (Kates et al. 2001). In consequence, attempts to handle urgency, complexity, interconnectivity and uncertainty may trigger difficult dilemmas and conflicting concerns in society. We, therefore, identify a sequence of stages included in the matrix (see Fig. 2 left side) for how to socially recognise, act upon and learn about sustainability challenges as interconnected problem syndromes:

- Scientific understanding Society creates and establishes structures to communicate, beyond scientific communities, the natural scientific knowledge on causes and magnitudes of the impacts of a particular sustainability challenge, like climate change ${ }^{3}$.

- Sustainability goals Society formulates and negotiates social goals, for one or multiple challenges, in political dialogues between society and science ${ }^{4}$.

- Sustainability pathways and strategies Society takes political decisions on pathways and strategies to fulfil the goals 5 .

- Implementation Society implements strategies, policies and measures while simultaneously initiating social learning processes to evaluate implementations and outcomes ${ }^{6}$.

\footnotetext{
3 The Intergovernmental Panel on Climate Change, formed in 1988, serves as an example of such a structure.

4 The UNFCC goal of stabilising greenhouse gases in the atmosphere (1992), the Millennium Development Goals (1999), and the WHO goals of eradicating epidemic diseases (1955 and 2007) are prominent examples.

5 The Stern Review (2006) offers examples of pathways that build on policies and measures in the Kyoto Protocol.

${ }^{6}$ Importantly, the implementation of one strategy (e.g. biofuel production) may compete with or have unintended consequences for other strategies (e.g. food security).
}

If sustainability science speaks with the Anthropocene vocabulary, then it means that sustainability challenges can only be met when the fundamental interconnections between nature and society are studied in more systematic, integrated and flexible ways (Kates et al. 2001; Ostrom 2009; Rockström et al. 2009). The strong tradition of separating natural and social sciences in academia has resulted in an inadequate understanding of nature-society interactions and the integrated dynamics of the 'Earth System' as a whole (Schellnhuber 1999; Steffen et al. 2004). We, therefore, suggest that researchers who collaborate across disciplines to adopt integrated approaches for overcoming the divide also seek to maintain reflective, reflexive and critical approaches to the Anthropocene imagery and to scientific representations in which nature and society are integrated as a whole (Lövbrand et al. 2009).

\section{Old and new concepts in sustainability science}

The structuring of the research field of sustainability science must draw upon scholarly work from a range of disciplines. Such a broad basis provides a crucial starting point for understanding theoretical and empirical multiplicities and addressing the urgency of sustainability challenges. This section describes the scientific connectivity. We proceed from the assumption that social and natural systems are characterised by complexity, non-linearity, self-organisation and strong interlinkages. Yet, there are fundamental differences between the systems. Natural systems are driven by a set of fundamental natural principles, such as gravity, thermodynamics and natural selection, while social systems are driven by totally different dynamics, such as demography, ideology, inequality and power struggles, as well as rationalisation, specialisation, institutionalisation, competition, capital accumulation, efficiency and technological change. From an anthropocentric perspective, natural systems have no purpose, while social systems may be goal-oriented and politicised. Intentionality may, thus, distinguish social from natural systems. The debate on linked social and natural systems often downplays this crucial difference, perhaps because it is still largely dominated by the natural sciences. We, therefore, need to consider the very foundation of sustainability and proceed from basic ontological and epistemological questions: what exists? What and how can we know about it? And what is the nature of that knowledge?

Our integrated approach to sustainability science is structured in accordance with the three-dimensional matrix in Fig. 2. In its present form, the matrix addresses only four sustainability challenges but we see it as a generic research platform to be applied to a range of sustainability 
issues. The matrix illustrates how research themes and questions in sustainability science can be conceptualised and organised in principle. It can also stimulate further analytical thought and insights into previously unknown or neglected aspects. The matrix comprises the following components:

Four sustainability challenges (see "Four sustainability challenges")

- Climate change

- Biodiversity loss

- Land use change

- Water scarcity

Three core themes (see "Three core themes")

- Scientific understanding

- Sustainability goals

- Sustainability pathways, strategies and implementation

Two cross-cutting approaches (see "Two cross-cutting approaches")

- Problem-solving approaches

- Critical research approaches

Four sustainability challenges

The research platform is applied here to four interrelated sustainability challenges in order to identify, explore and scrutinise the drivers of social and scientific change, be they social, economic, political, natural or technological.

\section{Climate change}

Global climate change is a reality confirmed by the $0.74^{\circ} \mathrm{C}$ increase in the global average temperature over the past century and the impacts are already evident (IPCC 2007c; Richardson et al. 2009). Changes in water availability, decreased food security, sea level rise, reduction in ice cover and increasing frequency and intensity of heat waves, storms, floods and droughts are projected to dramatically affect many millions of people. The likely range of humaninduced warming over the current century is between 1.4 and $6.4^{\circ} \mathrm{C}$ (IPCC 2007b). Moreover, climate change exacerbates the loss of biodiversity and degradation of land, soil, forest and water.

\section{Biodiversity loss}

The rate of species extinction is believed to be between one hundred and one thousand times faster than before the Industrial Revolution (Dirzo and Raven 2003; Reid et al. 2005). Recent estimates, however, indicate that it is expected to increase to as much as ten thousand times in coming decades (Chivian and Bernstein 2008), having disastrous consequences because biological diversity is a precondition for human well-being in terms of food, health and medicine, as well as immaterial values such as aesthetics, recreation and spiritual activities. A majority of all medicines used in the US and as much as $80 \%$ of medicines used in developing countries originate from biological organisms (Mindell 2009), while only a fraction of all species have been scientifically described and an even smaller fraction of identified species have been screened for useable substances (Beloqui et al. 2008). It is estimated that 15,000 out of 50,000-70,000 known medicinal plants are threatened by extinction (Li and Vederas 2009).

\section{Land use change and food production}

The global demand for food is expected to rise steeply as a result of burgeoning population, shifting dietary preferences and increasing demands for renewable energy (Hubert et al. 2010). In 2009, the FAO estimated that we must increase the global food production by $70 \%$ by 2050 in order to meet demands and needs (Schmidhuber and Tubiello 2007). This estimate was more recently challenged as an underestimation, thereby, further underlining the importance of the food problem (Tilman et al. 2002, 2010). At the same time, climate change, water scarcity and land use change are expected to jeopardise continued increases in agricultural production (Schmidhuber and Tubiello 2007; Battisti and Naylor 2009), thus, making food security a planetary emergency. This calls for a range of policies and creative solutions at the global, regional and local levels. In addition, there is an obvious risk that other important ecosystem services, such as clean water, biodiversity and protection against natural hazards, will be compromised in the search for agricultural land (UNEP 2007). The increasing competition for land to produce bioenergy is also a concern that may further aggravate food production and the international scramble for securing future food supplies. The situation is particularly problematic since the production of cereals per capita peaked in the mid-1980s and has since slowly decreased, despite the increase in average yields (Ramankutty et al. 2008).

\section{Water scarcity}

It is estimated that over a billion people worldwide lack access to safe drinking water and, if the current trend continues, there will be 1.8 billion people in regions with absolute water scarcity by 2025 (UNEP 2007). In addition, climate change will exacerbate water scarcity in certain regions, such as Northern India, and put another several hundred million people in acute water crisis. Global water 
and food security may, thus, be in jeopardy towards the middle or the end of the twenty-first century (IPCC 2007c).

Sustainability challenges are often defined and described by the natural sciences, and only later recognised as important for society and the social sciences. In contrast, the strength and innovation of an integrated approach is its ability to draw simultaneously on expertise from the natural sciences, social sciences and humanities to rethink, reconceptualise and reframe those challenges. As an example, we discuss distributional aspects of land, water and biodiversity in terms of access, allocation and agency along the three dimensions of international, intergenerational and intersectional justice. To that end, we borrow from existing theories and perspectives and, thus, expand concepts and analytical frames from classical disciplines into the domain of sustainability. All along, the dual critical and problemsolving research strategy is a frame that stimulates the generation of new theory and approaches for investigating complex issues.

\section{Three core themes}

\section{Theme one: scientific understandings of social-ecological systems}

Sustainability challenges, be it climate change or biodiversity loss, are normally defined and framed in natural scientific terms. Whereas the cognitive products of the natural sciences often shape how environmental problems are understood and acted upon in society, we know from years of social constructivist scholarship that science is far from autonomous from society, culture or the political. Rather, knowledge and beliefs about the natural world are embedded in the social world (Nowotny et al. 2001; Jasanoff and Martello 2004; Latour 2004). Building upon this insight, the first core theme involves four research efforts where connections between natural and social systems are understood and conceptualised. We, thus, show how research can critically scrutinise existing conceptual models and, on the basis of integrated research efforts, suggest improved understandings for sustainability science.

The research efforts discussed below represent different levels of theoretical ambition. Two grand theories, earth system science and world system dynamics of unequal exchange, aim to describe and explain global processes. Earth system analysis deals with the natural world from a natural scientific perspective (Schellnhuber 1999), whereas world system theory originally dealt with the world system from a sociological perspective (Wallerstein 1974) but more recently also from a 'green' political ecology perspective (Hornborg 1998; Wallerstein 2007), indicating that the two schools of thought can benefit from constructive dialogues. The two middle-range theories, resilience (Berkes et al. 2003) and material flow analysis, operate within more specifically defined scales, levels and systems. Resilience theory aims at understanding the dynamics of well-defined coupled social-ecological systems, such as a fishery, a wetland or a forest. Material flow analysis involves detailed mapping and accounting of observable units and processes in well-defined systems spanning local to global levels, such as the flow of metals and nutrients in time and space. Below, we introduce the grand and the middle-range theories, which can be critically and systematically applied.

The Earth system metaphor This sub-theme deals with emerging attempts to conceptualise and study natural and social systems as a single interrelated Earth system. According to this approach, the Earth system consists of two main components: the ecosphere with four subsystems (atmosphere, biosphere, hydrosphere, lithosphere) and the anthroposphere that accounts for all human activity (Schellnhuber 1999; Steffen et al. 2004). Building upon a view from space provided by remote sensing technology, global databases and sophisticated computer models, the quest of Earth system science is consequently to move beyond the study of each subsystem as a self-contained entity in favour of a holistic and interdisciplinary understanding of how they are connected and interlinked. While this approach acknowledges the complexity, non-linearity and surprise built into the coupled socio-ecological system,' it may also epitomise modern virtues such as rationality, control and predictability. Hence, this sub-theme can help scrutinise the tensions built into the Earth system metaphor and analyse their implications for the understanding of sustainability (Lövbrand et al. 2009).

The world system dynamics metaphor: theories of unequal exchange The world system perspective was created by economic historians and sociologists in the field of development theory (Wallerstein 1974), but is now also core to discussions on sustainability and political ecology. Whereas conventional economic science seems unable to accommodate concepts of unequal exchange, except in the sense of monopoly (i.e. market power), several strands of trans-disciplinary ecological economics are developing methodological tools for defining unequal exchange in objective, biophysical terms. Two potentially useful tools for assessing asymmetric resource flows are Ecological Footprints (Wackernagel et al. 2000) and Material Flow Analysis (Weisz 2007), as discussed below. Biophysical accounting tools, measuring the physical volumes exchanged or the land requirements of their production, tend to provide completely different perspectives on international trade than conventional economic statistics based on monetary value (Hornborg 2001; Martinez-Alier 
2002). These new approaches to global, societal metabolism are of crucial significance for the topic of sustainability. Climate change, for example, will be one major, to some extent predictable, driver of changes in the global distribution of vital ecosystem services, which can be integrated into existing frameworks for addressing and projecting exchange patterns.

Resilience of coupled social-ecological systems As an analytical framework, resilience emerged in ecology during the 1970s in reaction to ideas of equilibrium. Resilience depicts incremental changes and capacity to preserve systems within given frames (Holling 1973). However, in its original definition, resilience does not recognise that social change mainly implies transitions to new forms of production, consumption and distribution with new combinations of technology, organisation, institutions and lifestyles (Jerneck and Olsson 2008). The inner logic and utility of the increasingly popular resilience framework (Folke et al. 2002) should, therefore, be scrutinised.

Material flow analysis and various cycles Modern society is heavily dependent on manipulating a number of bio-geochemical cycles, such as: the carbon cycle for the provision of energy; the nitrogen and phosphorous cycles for the provision of food; and the water cycle for the provision of water, food, energy and transport. In the natural sciences, the study of such cycles has resulted in biogeochemistry, an area of scientific inquiry that integrates the disciplines of biology, geosciences and chemistry (Schlesinger 1997; Megonigal 2002). Material flow analysis (MFA) represents a similar development in the social sciences, as mentioned above. To some extent, MFA resembles macro-economic modelling, with the difference that MFA deals with physical units of materials rather than monetary units. The challenge to integrate the complete cycles, both the natural and the social components of these cycles, is at the very heart of sustainability science. But this requires a rethinking of the ontology and epistemology of disciplines. The natural science ontology of the carbon cycle is based on carbon as a bio-physical entity. If the ontology is reframed to incorporate also carbon used in the manufacturing, transporting and consumption of goods, then the cycling of carbon becomes as much a social as a natural cycle. Analogous reasoning of integration can be applied to the water and the nutrient cycles.

\section{Theme two: sustainability goals}

This theme explores the process of formulating and establishing various global sustainability goals, including their very content. Since the publication of 'Our Common Future' in 1987 (WCED 1987), social goal setting has changed from a broad qualitative vision of a sustainable society to more precise policies, including specific planning instruments and targets of efficiency and effectiveness that are measurable in quantitative terms, such as the Lisbon Agenda in the EU (Gros 2005).

The Brundtland Commission (WCED 1987) defined sustainable development as development that "meets the needs of the present without compromising the ability of future generations to meet their own needs." The concept, comprising environmental, economic and social pillars, is subject to criticism on many grounds, especially for its ambiguity and the lack of tangible operationalisation. The MDGs formulated in the United Nations Millennium Declaration (UN 2000) serve as an example of social goalsetting linked to a delivery system that attempts to contribute an operationalisation of sustainable development. One criticism against the MDGs is that they emphasise planning in top-down processes rather than the agency and participation of the people who are poor (Banuri 2005). Even more specific goals are set in the contexts of individual sustainability issues, such as the UN conventions (UNFCC, UNCBD etc.). Common to all such goals is that they are formulated through a complex interaction between science, politics, industry, media etc. Goals are also intimately and mutually related to scientific understanding. For example, the formulation of the MDGs has triggered many research initiatives specifically aimed at fostering scientific understandings that support the goals. The millennium development villages initiated and researched by the Earth Institute are an example (Cabral et al. 2006; Sanchez et al. 2007; Carr 2008; Diepeveen 2008). Sustainability goals can be critically examined from the point of view of three pertinent dimensions of justice and fairness, namely, the intergenerational, the international and the intersectional. Below, we list important research topics on this theme in relation to the three dimensions in the matrix as seen in Fig. 3.

Intergenerational justice and fairness Intergenerational justice is core to sustainability and has been discussed in relation to equity and law (Weiss 1990), energy policy

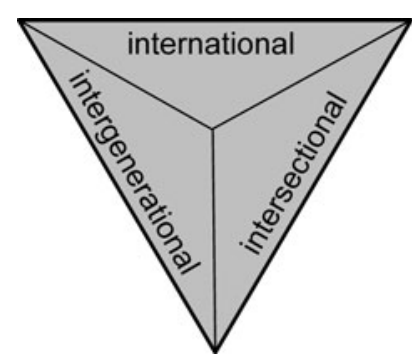

Fig. 3 Three dimensions of justice and fairness 
(Barry 1982) and climate policy (Page 1999). The dramatic differences between the conclusions of the Stern Review (Stern 2006) and previous investigations into the costs of climate change stem from differences in normative assumptions underlying the studies. The Review states explicitly that the welfare of future generations is as important as the welfare of the current generation, while most previous studies implicitly assume that the welfare of the current generation is more important than the welfare of future ones. The utilisation of finite resources is another important example. Can it be taken for granted that minerals found in geological deposits belong to the current generation? The problem of one generation reaping the benefits of a technology while leaving waste to future generations should be one of the most burning issues today, with renewed interest in nuclear energy. Should we build intergenerational justice into the exploitation of technology, and how can this be done? In relation to the notion of the cost-effectiveness of climate policies in the UNFCC, we may ask: cost-effective for whom (which generation)? (Hermele et al. 2009). These illustrations reflect theoretical challenges that can be subject to inquiry: in what sense can future agents have moral rights with respect to us and we have obligations with respect to them? How do collective obligations and responsibilities correspond to those of individual agents and how do the values of different aspects add up to values of wholes? An important component of these moral and legal problems is, in fact, descriptive and epistemic. How do we predict present and future needs and states of the world? How is this done in everyday life, in policy-making, in science and in law?

International justice and fairness Research in this field should deconstruct different aspects of the sustainability discourse in order to reveal biases and constraints. For instance, concern has been raised that climate change might trigger a new kind of world order founded on 'carbon colonialism' (Bäckstrand and Lövbrand 2006). Global problems related to climate change are, to a large extent, caused by the industrialised countries, but will have much more severe negative impacts on developing countries (World Bank 2009). In the struggle to reduce the emissions of greenhouse gases, developing countries are increasingly coerced into strategies that contribute to this polarisation rather than alleviating it. In subjecting the globalised discourse on sustainability to critical scrutiny, it could be an aim to uncover such tacit agendas, as it may reflect the perspectives and knowledge interests of affluent sectors of world society. Regarding control over natural resources such as oil, minerals and agricultural land, it may happen that bi-lateral and international policies violate international justice and fairness under the benign guise of development assistance (Lee 2006).
Intersectional justice and fairness The concept and analytical perspective of intersectionality focuses on "the relationship among multiple dimensions and modalities of social relations and subject formations" (McCall 2005). Intersectionality, thereby, reminds us that life worlds are multi-dimensional and identities entail combinations of age, class, ethnicity, race, religion, gender, sexual orientation etc. Apart from stressing multi-identities, intersectionality brings attention to power and takes into account that individuals may suffer simultaneous and multiple oppressions and inequalities in accordance with their identity. However, while some argue that the advantage of the term intersectionality is its intentional neutrality, others maintain that the political dimensions of inequality are washed away in the use of the concept (Hawthorne 2004). In resource governance, we may add the intersectional category of space such as upstream and downstream in water management or rural and urban in land use. Intersectionality is also used to explore dimensions of human identity in relation to sustainability goals. For instance, the MDGs are sometimes applauded for their gender awareness, while others argue that, by focusing on material and instrumental aspects in relation to gender, many other discriminatory aspects and intrinsic values are downplayed or not understood (Sweetman 2005). In sum, a sort of 'diversity matrix' (Hawthorne 2004) can be used to simultaneously scrutinise sustainability goals along several axes of identity.

\section{Theme three: sustainability pathways, strategies and implementation}

Science, politics, industry, media and civil society participate in complex multi-level dialogues to formulate strategies and pathways aiming at the fulfilment of sustainability goals. Such strategies are intimately and mutually related to scientific understandings, as well as to the political and economic context in which science is pursued. This is manifested in contesting views resulting in very different pathways, as illustrated by the Stern Review (Stern 2006). This theme serves to scrutinise pathways to sustainability by critically analysing proposed mechanisms for and pathways to sustainable societies. The broad domains of options available for the state are marketisation, regulation and democratisation (see Fig. 4).

Marketisation The public sector increasingly adopts values and practices from the private sector in fields such as health, education and environmental management. This marketisation trend is ubiquitous but particularly strong in transitionary economies with rapid industrialisation (Rigg 2006). As a response to the threat of global climate change, we see the emergence of a global carbon market and a new 


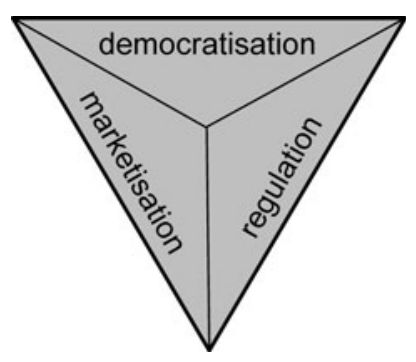

Fig. 4 Three domains of responses to sustainability challenges available for the state

'carbon economy.' The current global climate policy regime relies, to a large extent, on market mechanisms such as emissions trading, joint implementation and the Clean Development Mechanism. Regarding adaptation to climate change, insurance as an adaptation strategy represents a rapidly growing market where major financial players are increasingly active. Payments for environmental services (PES) is emerging as a universal tool for the integrated management of natural resources, such as biodiversity, water and soils (Pagiola et al. 2005). In the development debate, market integration is often described as a panacea (Sachs 2005). Proponents of marketisation argue that markets are most effective for dealing with problems, while opponents fear that this will compromise values related to democracy, citizenship (Eikenberry and Kluver 2004) and equity (Rigg 2006). In the context of this research agenda on sustainability challenges, marketisation can, thus, be scrutinised for its effectiveness and its impact on social justice.

Regulation There are profound challenges regarding legal regulations of sustainability. While environmental problems are often transboundary, much regulation is based on national law. New forms of regulative bodies transcending the nation state are, therefore, needed. Since there is no legal bearer of a right belonging to future generations, contemporary law is challenged by the intergenerational approach to sustainability. We, therefore, need more emphasis on both regulatory techniques and ethical principles (Gunningham et al. 2003). One initiative in this direction is seen in climate politics with the concept of the 'ensuring state' that serves as the catalyst, facilitator and provider of guarantees in relation to both citizens and other states; this would imply a new form of strong state (Giddens 2009). The new global research programme Earth System Governance aims to contribute to new forms of governance at the planetary (and local) level (Biermann et al. 2009). A suggested task here is to critically rethink contemporary regulative processes from a normative perspective.

Democratisation through deliberation The strong deliberative turn in democratic theory during recent decades speaks to an emerging concern with the distance between the interests and motives of citizens and the decisions made in their name (Smith 2003). A growing scholarship today questions liberal democratic institutions by pointing at the lack of voice of citizens and the poor representation of ecological values in decision-making processes (Dryzek 1997; Eckersley 2004). Deliberative democratic theory has evolved as a response to this perceived weakness of liberal democracy. It seeks to both democratise and to 'green' policy discourses by increasing the opportunities for citizens to engage in decisions that affect their lives and surrounding environment (Dobson 2003). The deliberative project also extends to the international arena and has been forwarded as a strategy that can bridge the democracy deficit in governance arrangements beyond the state (Nanz and Steffek 2005) and foster a trans-national green public sphere (Dryzek 1997). Research in this sub-theme should seek to examine how 'democratisation through deliberation' plays out in the environmental domain. We are particularly concerned with the potential synergies and tensions between the substantive and procedural aspects built into the deliberative project. As Goodin (1992) famously claimed, "( $t$ )o advocate democracy is to advocate procedures, to advocate environmentalism is to advocate substantive outcomes." Hence, how and to what extent can a deliberative model of democracy represent a pathway towards sustainability?

Two cross-cutting approaches

\section{Problem-solving and critical theories}

In 1981, Robert Cox (1981) made a seminal distinction between theories that seek to solve the problems posed within a particular perspective and critical theories that are more reflective upon the process of theorising itself. Problem-solving theory takes the world 'as it finds it,' with prevailing social and power relationships and the institutions into which they are organised as the given framework for action. The general aim within this school of thought is, according to Cox, to reduce a particular problem into a limited number of variables that can be studied with such precision that regularities of general validity can be identified. While problem-solving theory seeks to guide tactical actions and increase the efficiency of the existing institutional framework, critical theory stands apart from the prevailing order of the world and asks 'how it came about.' Unlike problem-solving theory, critical theory calls contemporary institutions and power relations into question and allows for a normative choice in favour of alternative social and political orders. With an example from climate change research, problem-solving research could deal with how to optimise an emissions 
trading scheme, while critical research would question the very existence of market-based mechanisms such as trading schemes as solutions to climate change. While acknowledging that each school of thought has its strengths and weaknesses, Cox (1981) affirmed that there is no such thing as a theory in itself divorced from a standpoint in time and space; theory is always for someone and for some purpose.

This epistemological claim functions as an organising principle in the matrix described in Fig. 2. The integrated research proceeds from different disciplinary perspectives and is grounded in both problem-solving and critical approaches, wherein epistemological reflexivity is a necessary prerequisite for successful interdisciplinary dialogue and integration to be discussed below.

\section{Towards sustainability science}

The critical analysis of natural scientific understanding, sustainability goals and sustainability pathways can serve as a basis for building theories and methods in sustainability science that can transcend the following crucial divides described.

\section{Nature and society}

The lack of theories on nature-society interaction is a hurdle. Yet, a number of new approaches with different origins and with their own biases, strengths and weaknesses are emerging to bridge the gap between natural sciences and social sciences: industrial ecology (Ayres 1994; Fischer-Kowalski and Haberl 1997; Anderberg 1998), ecological economics (Costanza 1997), transition theory (Rotmans et al. 2001), resilience theory (Folke et al. 2002), cultural theory (Verweij et al. 2006) and world systems analysis (Hornborg and Crumley 2006). Theories that capture the dynamic linkages between natural and social systems are, thus, in progress.

Many integrative efforts in sustainability science rely on system thinking and modelling, scenario construction, envisioning exercises, and regional or spatial integration. Efforts to assess sustainability and translate science into policy or planning processes at different levels are dominated by combinations of these approaches. The challenge is to move beyond these established approaches by focussing more on the dynamics of social, economic and political systems in relation to nature, ecology and the environment. Examples of this include research on coupled systems (Ostrom 2009) and coupled systems under pressure from globalisation (Young et al. 2006). Research into the integration of social and natural cycles could be a concrete task in this context (AIMES 2009).
Science and society

Theories and approaches that capture how scientific understanding of socio-ecological systems can contribute to global sustainability are also in progress, as exemplified by the Earth System Governance Project (Biermann et al. 2009) and the debate on governance and governing for sustainability, highlighting theoretical and empirical aspects of how governance operates and how it should operate (Adger and Jordan 2009). Studies on multi-level interactions between informal (e.g. norms, conduct, behaviours) and formal (e.g. regulation) institutions (Checkland and Scholes 1990) should be promoted.

Research focusing on knowledge flows between science and society is also underway (Cash et al. 2003; Jäger 2009a, b). Related research in sustainability science explores how scientists can navigate between the demand to provide effective policy advice on the planetary lifesupport system and the calls for socially robust knowledge and legitimate expertise that is open for plural viewpoints and public deliberation (Nowotny et al. 2001). But this can probably only be done in interactive participatory processes such as Integrated Sustainability Assessment (ISA) (Weaver and Rotmans 2006). In addition, efforts should be made to further develop and refine methods for stakeholder interaction (Loorbach and Rotmans 2006) to be combined with scenario construction, systems analysis and system dynamics.

\section{Critical and problem-solving research}

Differences in ontology and epistemology constitute one of the main obstacles to the integration of knowledge across scientific disciplines (Feyerabend 1991), especially when values, conflicting goals and difficult choices are involved. Methodology is, therefore, no trivial issue in sustainability science. Methods are rooted in (some) methodology and are, therefore, not neutral, whereas techniques are often more neutral in the sense that they are less associated with a particular methodology. Broad research tools, like GIS and system analysis can, if they make theory and methodology explicit, assist scholars in designing and pursuing research while ensuring a high scientific standard in terms of constructing, interpreting and evaluating data. As an example, there are attempts to combine system analysis and spatial dynamics into a single conceptual framework that helps reveal the interlinkages between different domains at a variety of scales and levels (Ness et al. 2010).

In the pursuit of knowledge, we prioritise problemsolving while critically questioning conditions that created problems of un-sustainability in the first place. This is a reflexive approach for breaking out of a particular reference frame in order to reap the benefit of seeing beyond its 
boundaries. Reframing is constructive for problem resolution; it is also a useful tool for bridging critical and problem-solving research (Olsson and Jerneck 2009).

\section{A LUCID example}

This section shows how sustainability science research is organised and pursued at the Lund University Centre of Excellence for Integration of Social and Natural Dimensions of Sustainability (LUCID), which is a decadal effort to work jointly on the theory, methodology and education for sustainability. Research on complex issues is usually best pursued when researchers with different but related expertise and experiences form groups to investigate various aspects of a joint problem (Sherren et al. 2009). LUCID is an example of such collaboration. It is guided by the idea of being an arena for research and education that advances the role of science in transitions towards sustainability.

In LUCID, senior and junior researchers jointly organise interdisciplinary seminars and workshops; co-author articles and books as well as conference papers; design PhD courses and participate in joint supervision of $\mathrm{PhD}$ candidates. Such team work with feedback sessions serve as a forum to discuss, scrutinise and refine ideas and data, thereby, further improving the theoretical and methodological awareness, as well as research quality. In addition, researchers prepare annual 'LUCID Assessments' of timely sustainability issues, such as international land conflicts, which serve to highlight their urgency, as well as increase the dialogue between academia and policymakers. LUCID is also a member of significant international networks on sustainability, such as the Right Livelihood College and the Earth System Governance Project within the International Human Dimensions Programme (IHDP) (Biermann et al. 2009).

LUCID aims at a progressive integration of knowledge production and collaboration as illustrated in the three symbols in Fig. 5. The first phase is multi-disciplinary, the second phase is interdisciplinary and the third phase is transdisciplinary.

For the purpose of illustrating how sustainability science can be structured in practice, we offer one LUCID example that is located at the nexus of multiple sustainability challenges - climate change, deforestation, ill health-in the context of poverty and subsistence farming in Kenya. The research effort is long-term and action-oriented. It aims at problem-solving while taking a critical stance on how old social problems and new sustainability challenges are tackled in research and development practice (Olsson and Jerneck 2010). In search of sustainability pathways, we set up intervention research in 2008 with subsistent farmers as local stakeholders by reframing them from vulnerable victims of multiple stressors into agents fighting livelihood stressors and impacts of climate change. In knowledge coproduction, we conducted small-scale experiments for addressing domestic energy inefficiency (indoor cooking over open fire) and related health problems from indoor air pollution (respiratory diseases due to the smoke). An empirically grounded solution, the smokeless kitchen, emerged when local craftsmen and women collaborated to design, produce, test and install energy-saving cooking
Fig. 5 Expected organisational progress and scientific achievements for LUCID, 2008-2018

\begin{tabular}{|c|c|c|c|}
\hline achieve & $\begin{array}{l}\text { Phase } 1 \\
\text { (year 1-2) }\end{array}$ & $\begin{array}{l}\text { Phase } 2 \\
\text { (year 3-5) }\end{array}$ & $\begin{array}{l}\text { Phase } 3 \\
\text { (year 6-10) }\end{array}$ \\
\hline $\begin{array}{l}\text { Theoretical } \\
\text { development }\end{array}$ & $\begin{array}{l}\text { Multidisciplinarity. } \\
\text { Researchers from } \\
\text { different disciplines } \\
\text { co-operate across } \\
\text { their own theories } \\
\text { and perspectives }\end{array}$ & $\begin{array}{l}\text { Interdisciplinarity. } \\
\text { Ontological approaches } \\
\text { are questioned resulting } \\
\text { in a co-evolution of theories } \\
\text { for sustainability science }\end{array}$ & $\begin{array}{l}\text { Transdisciplinarity. } \\
\text { Theories evolve and } \\
\text { mature to gradually } \\
\text { incorporate more domains } \\
\text { and transcend the boundary } \\
\text { between science and practice }\end{array}$ \\
\hline $\begin{array}{l}\text { Methodological } \\
\text { development }\end{array}$ & $\begin{array}{l}\text { Different disciplines } \\
\text { apply their own tools } \\
\text { and methods on joint } \\
\text { research problems }\end{array}$ & $\begin{array}{l}\text { Tools and methods for } \\
\text { sustainablity science } \\
\text { evolve along with theories. } \\
\text { Participatory approaches } \\
\text { are increasingly important }\end{array}$ & $\begin{array}{l}\text { Research increasingly } \\
\text { follows participatory and goal } \\
\text { oriented approaches while } \\
\text { being reflexive. Integration } \\
\text { of external stakeholders } \\
\text { in the research }\end{array}$ \\
\hline $\begin{array}{l}\text { Organisational } \\
\text { development }\end{array}$ & $\begin{array}{l}\text { LUCID is an arena } \\
\text { where different disciplines } \\
\text { meet but are not integrated. } \\
\text { Some researchers are } \\
\text { located at LUCID, some } \\
\text { at their home departments }\end{array}$ & $\begin{array}{l}\text { Closer interaction between } \\
\text { researchers requires common } \\
\text { premises. The PhD programme } \\
\text { in sustainability science, started } \\
\text { in phase } 1 \text {, is further developed }\end{array}$ & $\begin{array}{l}\text { Disciplines external to LUCID } \\
\text { are increasingly involved. The } \\
\text { Centre of Excellence is } \\
\text { instrumental in structural } \\
\text { renewal of many knowledge } \\
\text { fields related to sustainability }\end{array}$ \\
\hline $\begin{array}{l}\text { Educational } \\
\text { development }\end{array}$ & $\begin{array}{l}\text { Close interdepartmental } \\
\text { cooperation in related but } \\
\text { independent Masters } \\
\text { programmes }\end{array}$ & $\begin{array}{l}\text { Masters programmes covering } \\
\text { different aspects of } \\
\text { sustainability (social, economic, } \\
\text { environmental) become more } \\
\text { and more integrated }\end{array}$ & $\begin{array}{l}\text { Apart from Masters programmes } \\
\text { in sustainability science, other } \\
\text { fields adopt sustainability as a } \\
\text { major component resulting in } \\
\text { many co-operating programmes }\end{array}$ \\
\hline
\end{tabular}


stoves with flue pipes that solved multiple problems: the exposure to dangerous smoke, the high demand for fuel wood and the heavy workload for women and children to collect the wood. As a result, the smokeless kitchen also reduces climate change forcing from the emissions of black carbon and greenhouse gases while contributing to decreased deforestation. In addition, the social learning process can develop to deal with other problems, such as water scarcity and water provision.

\section{Conclusion}

In this article, we have introduced a research agenda with a generic research platform for how research in sustainability science can be structured and conducted while integrating problem-solving with critical research. In particular, science needs to establish profound understandings that can be harnessed and used by society in political processes where social goals, policies and strategies for tackling a range of sustainability challenges are formulated, negotiated, implemented and, also, evaluated. Moreover, in sustainability science, it is expected that interdisciplinary groups of researchers engage in such transdisciplinary processes in order to demonstrate how sustainability transitions for society can come about, as illustrated here. Except for the informed discussion on the challenges and how they can be structured and tackled theoretically and conceptually, the main significance of the research platform and the matrix launched in the article lies in the methodological approach. Problem-solving research and critical research are often pursued in different camps of academia but, here, we suggest that they must cooperate in a dialectic and reflexive mode.

Acknowledgment This research is funded by a Linnaeus Research Grant (http://www.lucid.lu.se) from the Swedish research foundation Formas. The authors thank the three anonymous reviewers for their constructive comments.

\section{References}

Adger WN, Jordan A (eds) (2009) Governing sustainability. Cambridge University Press, Cambridge

Analysis, Integrationand Modelling of theEarth System (AIMES) (2010) Science plan and implementation strategy. IGBP Report No. 58. IGBP Secretariat, Stockholm, $30 \mathrm{pp}$

Anderberg S (1998) Industrial metabolism and the linkages between the ethics, economy and the environment. Ecol Econ 24:211-220

Ayres RU (1994) Industrial metabolism: theory and policy. In: Ayres RU, Simonis UK (eds) Industrial metabolism: restructuring for sustainable development. United Nations University Press, Tokyo, pp 3-20

Bäckstrand K (2003) Civic science for sustainability: reframing the role of experts, policy-makers and citizens in environmental governance. Glob Environ Politics 3(4):24-41
Bäckstrand K, Lövbrand E (2006) Planting trees to mitigate climate change: contested discourses of ecological modernization, green governmentality and civic environmentalism. Glob Environ Politics 6(1):50-75

Banuri T (2005) Approaches to poverty eradication. Review of: Investing in development: a practical plan to achieve the Millennium Development Goals. Environment 47(9):39-43

Barry B (1982) Intergenerational justice in energy policy. University of Maryland, College Park, p 21

Battisti DS, Naylor RL (2009) Historical warnings of future food insecurity with unprecedented seasonal heat. Science 323(5911):240-244

Beloqui A, de María PD, Golyshin PN, Ferrer M (2008) Recent trends in industrial microbiology. Curr Opin Microbiol 11(3):240-248

Berkes F, Colding J, Folke C (2003) Navigating social-ecological systems: building resilience for complexity and change. Cambridge University Press, Cambridge

Biermann F, Betsill MM, Gupta J, Kanie N, Lebel L, Liverman D, Schroeder H, Siebenhüner B (2009) Earth system governance: people, places and the planet. Earth system governance project report 1. Earth System Governance Project, Bonn

Cabral L, Farrington J, Ludi E (2006) The Millennium Villages Project-a new approach to ending rural poverty in Africa? Nat Resour Perspect 101:1-4

Carr ER (2008) The millennium village project and African development: problems and potentials. Prog Dev Stud 8(4):333-344

Cash DW, Clark WC, Alcock F, Dickson NM, Eckley N, Guston DH, Jäger J, Mitchell RB (2003) Knowledge systems for sustainable development. Proc Natl Acad Sci 100(14):8086-8091

Checkland P, Scholes J (1990) Soft systems methodology in action. Wiley, Chichester

Chivian E, Bernstein A (2008) Sustaining life: how human health depends on biodiversity. Oxford University Press, USA

Clark WC, Dickson NM (2003) Sustainability science: the emerging research program. Proc Natl Acad Sci 100(14):8059-8061

Costanza R (1997) An introduction to ecological economics. CRC Press, Boca Raton

Cox RW (1981) Social forces, states and world orders: beyond international relations theory. Millennium 10(2):126-155

Crutzen PJ (2002) Geology of mankind. Nature 415(January):23

Crutzen PJ, Steffen W (2003) How long have we been in the Anthropocene era. Clim Change 61(3):251-257

Deutsch CH (2007) A threat so big, academics try collaboration. New York Times, New York

Diepeveen S (2008) Putting Empowerment into practice: evaluating the potential for "Development as Freedom" in the Millennium Villages Project. Undercurr J 5(1):6-13

Dirzo R, Raven PH (2003) Global state of biodiversity and loss. Ann Rev Environ Resour 28(1):137-167

Dobson A (2003) Citizenship and the environment. Oxford University Press, Oxford

Dryzek JS (1997) The politics of the earth. Environmental discourses. Oxford University Press, Oxford

Eckersley R (2004) The green state. Rethinking democracy and sovereignty. MIT Press, Cambridge

Eikenberry AM, Kluver JD (2004) The marketization of the nonprofit sector. Civil society at risk? Public Admin Rev 64(2):132-140

Ferrer-Balas D, Lozano R, Huisingh D, Buckland H, Ysern P, Zilahy $\mathrm{G}$ (2010) Going beyond the rhetoric: system-wide changes in universities for sustainable societies. J Cleaner Prod 18(7):607-610

Feyerabend PK (1991) Three dialogues on knowledge. Blackwell, Oxford

Fischer-Kowalski M, Haberl H (1997) Tons, joules, and money: modes of production and their sustainability problems. Soc Nat Resour 10(1):61-85 
Folke C, Carpenter S, Elmqvist T, Gunderson L, Holling CS, Walker B, Bengtsson J, Berkes F, Colding J, Danell K, Falkenmark M, Gordon L, Kasperson R, Kautsky N, Kinzig A, Levin S, Mäler K-G, Moberg F, Ohlsson L, Olsson P, Ostrom E, Reid W, Rockström J, Savenije H, Svedin U (2002) Resilience and sustainable development: building adaptive capacity in a world of transformations. Sustainable Development. ICSU, Paris, p 73

Giddens A (2009) The politics of climate change. Polity Press, Cambridge

Goodin RE (1992) Green political theory. Polity Press, Cambridge

Gros D (2005) Prospects for the Lisbon Strategy: how to increase the competitiveness of the European economy? CEPS Working Document No. 224

Gunningham N, Kagan RA, Thornton D (2003) Shades of green: business, regulation, and environment. Stanford University Press, Stanford

Gupta J, Persson A, Olsson L, Linnerooth-Bayer J, van der Grijp N, Jerneck A, Klein RJT, Thompson M, Patt A (2010) Mainstreaming climate change in development cooperation policy: conditions for success. In: Hulme M, Neufeldt $\mathrm{H}$ (eds) Making Climate Change Work for Us. European perspectives on adaptation and mitigation strategies. Cambridge University Press, Cambridge, pp 319-339

Haines-Young R, Potschin M, Chesire D (2006) Defining and identifying environmental limits for sustainable development. A scoping study. Final overview report to Defra, Project Code NR0102. University of Nottingham, Centre for Environmental Management, Nottingham

Hawthorne S (2004) The political uses of obscurantism: gender mainstreaming and intersectionality. Dev Bull 64:87-91

Hermele K, Olsson L, Jerneck A (2009) Justice and fairness in resource governance: conflicting views on allocation and access. 2009 Amsterdam Conference on Human Dimensions of Global Environmental Change, Amsterdam

Holling CS (1973) Resilience and stability of ecological systems. Annu Rev Ecol Syst 4:1-23

Hornborg A (1998) Towards an ecological theory of unequal exchange: articulating world system theory and ecological economics. Ecol Econ 25(1):127-136

Hornborg A (2001) The power of the machine: global inequalities of economy, technology, and environment. AltaMira Press, USA

Hornborg A, Crumley CL (2006) The World System and the Earth System: global socioenvironmental change and sustainability since the Neolithic. Left Coast Press, Walnut Creek

Hotez PJ, Molyneux DH, Fenwick A, Kumaresan J, Sachs SE, Sachs JD, Savioli L (2007) Control of neglected tropical diseases. N Engl J Med 357(10):1018-1027

Hubert B, Rosegrant M, van Boekel MAJS, Ortiz R (2010) The future of food: scenarios for 2050. Crop Sci 50(Supplement 1):33-50

Intergovernmental Panel on Climate Change (IPCC) (2007a) Summary for policymakers. Climate Change 2007: Mitigation. In: Metz B, Davidson OR, Bosch PR, Dave R, Meyer LA (eds) Contribution of Working Group III. Cambridge University Press, Cambridge

Intergovernmental Panel on Climate Change (IPCC) (ed) (2007b) Climate Change 2007: the physical science basis. Oxford University Press, Oxford

Intergovernmental Panel on Climate Change (IPCC) (2007c) Climate Change 2007: impacts, adaptation and vulnerability. Oxford University Press, Oxford

Irwin A (1995) Citizen science: a study of people, expertise and sustainable development. Routledge, London

Jäger J (2009a) The governance of science for sustainability. In: Adger WN, Jordan A (eds) Governing sustainability. Cambridge University Press, Cambridge, pp 142-158
Jäger J (2009b) Sustainability science in Europe. European Commission, Vienna

Jasanoff S, Martello ML (2004) Earthly politics: local and global in environmental governance. MIT Press, Cambridge

Jerneck A, Olsson L (2008) Adaptation and the poor-development, resilience and transition. Clim Policy 8(2):170-182

Kates RW, Clark WC, Correll R, Hall JM, Jaeger CC, Lowe I, McCarthy JJ, Schellnhuber HJ, Bolin B, Dickson NM, Faucheux S, Gallopin GC, Grübler A, Huntley B, Jäger J, Jodha NS, Kasperson RE, Mabogunje A, Matson P, Mooney H, Moore B III, O'Riordan T, Svedin U (2001) Sustainability science. Science 292(5517):641-642

Kleinman DL (2001) Science, technology, and democracy. New York State University Press, Albany

Latour B (2004) Politics of nature. How to bring the sciences into democracy. Harvard University Press, Cambridge

Leach M, Scoones I, Wynne B (2007) Science and citizens. Globalization and the challenge of engagement. Zed Books, London

Lee MC (2006) The 21st century scramble for Africa. J Contemp Afr Stud 24(3):303-330

Li JW-H, Vederas JC (2009) Drug discovery and natural products: end of an era or an endless frontier? Science 325(5937):161-165

Loorbach D, Rotmans J (2006) Managing transitions for sustainable development. Understanding Industrial Transformation, pp 75-98

Lövbrand E, Stripple J, Wiman B (2009) Earth System governmentality: reflections on science in the Anthropocene. Glob Environ Change 19(1):7-13

Martinez-Alier J (2002) The environmentalism of the poor: a study of ecological conflicts and valuation. Edward Elgar, Cheltenham

McCall L (2005) The complexity of intersectionality. Signs J Women Cult Soc 30(3):1771-1800

Megonigal JP (2002) Global natural cycles in Earth's System. In: Cilek V (ed) Encyclopedia of life support systems. EOLSS Publishers, Oxford

Mindell DP (2009) Environment and health: humans need biodiversity. Science 323(5921):1562-1563

Nanz P, Steffek J (2005) Assessing the democratic quality of deliberation in international governance: criteria and research strategies. Acta Politica 40:368-383

Nature (2007) The university of the future (editorial). Nature 446(7139):949

Ness B, Anderberg S, Olsson L (2010) Structuring problems in sustainability science: the multi-level DPSIR framework. Geoforum 41(3):479-488

Nowotny H, Gibbons M, Scott P (2001) Re-thinking science. Sage Publications, London

Olsson L, Jerneck A (2009) Analytical reframing-a methodological approach in sustainability science. 2009 Annual Meeting of Social Studies of Science in Society. Social Studies of Science in Society, Washington, DC

Olsson L, Jerneck A (2010) Farmers fighting climate change-from victims to agents in subsistence livelihoods. Wiley Interdiscip Rev Clim Change 1(May/June):363-373

Oreskes N (2004) The scientific consensus on climate change. Science 306(December): 1686

Ostrom E (2009) A general framework for analyzing sustainability of social-ecological systems. Science 325(July):419-422

Page E (1999) Intergenerational justice and climate change. Political Stud 47(1):53-66

Pagiola S, Arcenas A, Platais G (2005) Can payments for environmental services help reduce poverty? An exploration of the issues and the evidence to date from Latin America. World Dev 33(2):237-253 
Ramankutty N, Foley J, Olejniczak N (2008) Land-use change and global food production. In: Braimoh AK, Vlek PLG (eds) Land use and soil resources. Springer, New York, pp 23-40

Reid WV, Mooney HA, Cropper A, Capistrano D, Carpenter SR, Chopra K, Dasgupta P, Dietz T, Duraiappah AK, Hassan R, Kasperson R, Leemans R, May TRM, McMichael AJ, Pingali P, Samper C, Scholes R, Watson RT, Zakri AH, Shidong Z, Ash NJ, Bennett E, Kumar P, Lee MJ, Raudsepp-Hearne C, Simons H, Thonell J, Zurek M (2005) The Millennium Ecosystem Assessment: ecosystems and human well-being: synthesis. World Resources Institute, Washington, DC

Richardson K, Steffen W, Schellnhuber HJ, Alcamo J, Barker T, Kammen DM, Leemans R, Liverman D, Munasinghe M, OsmanElasha B, Stern N, Waever O (2009) Synthesis report: climate change, global risks, challenges \& decisions. University of Copenhagen, Copenhagen

Rigg JD (2006) Forests, marketization, livelihoods and the poor in the Lao PDR. Land Degrad Dev 17:123-133

Rittel HWJ, Webber MM (1972) Dilemmas in a general theory of planning. Policy Sci 4:155-169

Rockström J, Steffen W, Noone K, Persson A, Chapin FS, Lambin EF, Lenton TM, Scheffer M, Folke C, Schellnhuber HJ, Nykvist B, de Wit CA, Hughes T, van der Leeuw S, Rodhe H, Sörlin S, Snyder PK, Costanza R, Svedin U, Falkenmark M, Karlberg L, Corell RW, Fabry VJ, Hansen J, Walker B, Liverman D, Richardson K, Crutzen P, Foley JA (2009) A safe operating space for humanity. Nature 461(7263):472-475

Rotmans J, Kemp R, van Asselt M (2001) More evolution than revolution: transition management in public policy. Foresight $3(1): 15-31$

Sachs JD (2005) The end of poverty, how we can make it happen in our lifetime. Penguin, London

Sanchez P, Palm C, Sachs J, Denning G, Flor R, Harawa R, Jama B, Kiflemariam T, Konecky B, Kozar R (2007) The African millennium villages. Proc Natl Acad Sci 104(43):16775-16780

Schellnhuber HJ (1999) 'Earth system' analysis and the second Copernican revolution. Nature 402:C19-C23

Schlesinger WH (1997) Biogeochemistry: an analysis of global change. Academic Press, San Diego

Schmidhuber J, Tubiello FN (2007) Climate change and food security special feature: global food security under climate change. Proc Natl Acad Sci 104(50):19703-19708

Sherren K, Klovdahl A, Robin L, Butler L, Dovers S (2009) Collaborative research on sustainability: myths and conundrums of interdisciplinary departments. J Res Pract 5(1):1-29

Smith G (2003) Deliberative democracy and the environment. Routledge, London

Steffen W, Sanderson A, Tyson PD, Jäger J, Matson PA, Moore B III, Oldfield F, Richardson K, Schellnhuber HJ, Turner BL II, Wasson RJ (2004) Global change and the earth system. A planet under pressure. Springer, Berlin

Stern N (2006) The economics of climate change-the Stern review. Cambridge University Press, Cambridge

Sweetman C (2005) Editorial. Gend Dev 13(1):2-8

Tilman D (2010) Understanding the present and projecting the future of global food demand. AAAS Annual Meeting 2010. AAAS, San Diego
Tilman D, Cassman KG, Matson PA, Naylor R, Polasky S (2002) Agricultural sustainability and intensive production practices. Nature 418(6898):671-677

United Nations (2000) Millennium declaration. General assembly declaration 55/2 (18 September 2000)

United Nations Development Program (UNDP) (2007) Human development report 2007/2008. Fighting climate change: human solidarity in a divided world. United Nations Development Program, New York

United Nations Development Program (UNDP) (2009) Human development report 2009. Overcoming barriers: human mobility and development. United Nations Development Program, New York

United Nations Environment Programme (UNEP) (2007) Global environmental outlook 4. United Nations Environment Programme, Nairobi

Verweij M, Douglas M, Ellis R, Engel C, Hendriks F, Lohmann S, Ney S, Rayner S, Thompson M (2006) Clumsy solutions for a complex world: the case of climate change. Public Admin 84(4):817-843

Wackernagel M, Linares AC, Deumling D, Vasquesz-Sanches MA, Lopez-Falfan IS, Loh J (2000) Ecological footprints and ecological capacities of 152 nations. Redefining Progress, Oakland

Walker B, Barrett S, Polasky S, Galaz V, Folke C, Engström G, Ackerman F, Arrow K, Carpenter S, Chopra K, Daily G, Ehrlich P, Hughes T, Kautsky N, Levin S, Mäller K-G, Shogren J, Vincent J, Xepapadeas T, de Zeeuw A (2009) Looming global-scale failures and missing institutions. Science 325(5946): 1345-1346

Wallerstein I (1974) The modern world-system, 3 vols (1974-89). Academic Press, London

Wallerstein I (2007) The ecology and the economy: what is rational? In: Hornborg A, McNeill RJ, Martinez-Alier J (eds) Rethinking environmental history: world-system history and global environmental change. AltaMira Press, New York

Weaver P, Jansen L (2004) Defining and evaluating 'science for sustainability'. International Conference on Sustainability Engineering and Science, Auckland, New Zealand

Weaver PM, Rotmans J (2006) Integrated sustainability assessment: what, why and how. Int J Innov Sustain Dev 1(4):284-303

Weiss EB (1990) Our rights and obligations to future generations for the environment. Am J Int Law 84(1):198-207

Weisz H (2007) Combining social metabolism and input-output analyses to account for ecologically unequal trade. In: Hornborg A, McNeill RJ, Martinez-Alier J (eds) Rethinking environmental history: world-system history and global environmental change. AltaMira Press, New York

World Bank (2007) World development report 2008: agriculture for development. World Bank, Washington, DC

World Bank (2009) World Development report 2010: development in a changing climate. World Bank, Washington, DC

World Commission on Environment and Development (WCED) (1987) Our common future. Oxford University Press, Oxford

Young OR, Berkhout F, Gallopin GC, Janssen MA, Ostrom E, van der Leeuw S (2006) The globalization of socio-ecological systems: an agenda for scientific research. Glob Environ Change $16: 304-316$ 